\title{
Empiryzm dla językoznawstwa W poszukiwaniu nowego ujęcia
}

\section{Mieszko Tałasiewicz}

\section{Uniwersytet Warszawski}

$\mathrm{Na}$ początek pewna uwaga na temat metodologii... tego tekstu. Nie jestem językoznawcą. Jestem filozofem języka. Postrzegam język w nieco innej perspektywie niż językoznawcy. W innej perspektywie niż językoznawcy postrzegam też samo językoznawstwo i charakterystyczne dla tej dyscypliny problemy i dylematy metodologiczne. Odpowiednio trzeba też rozumieć niniejszy tekst. Należy on do dialogu interdyscyplinarnego. Na pewno nie jest, nie może być i nie był nigdy zamierzony jako tekst przedstawiający metodologię językoznawczą 'od wewnątrz', z całym arsenałem językoznawczych odniesień lecz 'od zewnątrz'. Nie przedstawiam w nim problemów nurtujących językoznawców, lecz trudności metodologiczne, jakie widzi filozof języka, kiedy chciałby oprzeć się na wynikach 'twardej' nauki (i kiedy mu się ta nauka 'ugina'...).

W moim przekonaniu jednym z najgłębszych: zarazem najważniejszych i najtrudniejszych problemów metodologicznych w badaniach nad językiem naturalnym w ogóle, a nad składnią w szczególności ${ }^{1}$, jest problem znalezienia właściwej miary w 'empiryczności' badań, czyli mówiąc ściślej, właściwego sposobu ujęcia zjawisk językowych (składniowych).

Gdy chcemy badać ogólną strukturę języka, odkrywać jakieś regularności i formułować teorię opisującą te regularności i wyjaśniającą zjawiska, musimy w jakimś stopniu abstrahować od przypadkowych szczegółów; od unikalnych refleksów czyjegoś idiolektu użytego w przypadkowych okolicznościach komunikacyjnych. Jeżeli tego nie zrobimy, grozi nam popadnięcie w skrajność, którą Peter Thomas Geach (1970) nazwał 'idiotyzmem idiomu' (idiotism of idiom), a której ostatecznym skutkiem jest produkowanie ogromnej ilości teorii,

\footnotetext{
${ }^{1}$ Uwagi przedstawione $\mathrm{w}$ tym artykule motywowane są przede wszystkim rozważaniami nad metodologią teorii składni. Sądzę jednak, że wiele z tego, co tu zostanie powiedziane, tyczyć się może badań nad językiem w ogóle, nie tylko nad składnią.
} 
niemożliwych do zunifikowania i w sumie niewiele wyjaśniających: niemal każde zjawisko językowe wymaga oddzielnej teorii.

Ucieczka od 'idiotyzmu idiomu' wydawać się może bardzo łatwa - zwłaszcza z perspektywy filozofa. Wystarczy przyjąć postawę charakterystyczną dla niektórych logików, a zwięźle przedstawioną przez Davida Lewisa. Autor „General semantics” ujął to tak:

Rozróżniam dwie kwestie: po pierwsze - kwestię opisu możliwych języków czy gramatyk jako abstrakcyjnych systemów semantycznych, w których symbole są skojarzone z aspektami świata; i po drugie - kwestię opisu psychologicznych i socjologicznych faktów, za sprawą których jeden z tych abstrakcyjnych systemów semantycznych staje się tym, którego używa jakaś osoba lub populacja. Tylko zamęt wynika z pomieszania tych kwestii ${ }^{2}$ (Lewis 1970: 19).

Wielu filozofów języka istotnie taką postawę przyjmuje, nawet takich, którzy - jak Kazimierz Ajdukiewicz (1960/1985: 344) - uważaja, że sztuczne języki badane przez logikę „można, jak się zdaje [...] uważać za idealizację języków naturalnych". Postawa taka, stanowiąca przeciwną skrajność, jest jednak bardzo niewygodna dla kogoś, kogo nurtuje charakterystyczna dla postawy przyrodnika, a obca duchowi filozofii spekulatywnej ciekawość, 'jak jest naprawdę' (in the vernacular) - a więc zarówno dla językoznawców, jak i dla tych filozofów, którzy chcą badać ludzki język jako realny fenomen.

Ta ciekawość sprowadza nas z wysokiej abstrakcji języków sztucznych z powrotem $\mathrm{w}$ świat konkretów i ciągnie w dół, w stronę 'idiotyzmu idiomu'. To przez nią musimy się przed tym 'idiotyzmem' bronić. Musimy zatrzymać się dostatecznie wysoko, by móc stworzyć teorię zarazem ogólną (a więc wyidealizowana), ale i dobrze ugruntowaną w doświadczeniu (opisującą język naturalny, a nie sztuczny). Innymi słowy, kluczowym problemem jest wskazanie właściwego zasięgu idealizacji; abstrahowanie od tego, co nieistotne, a pozostawienie tego, co istotne.

Pierwszą reakcją na tak postawiony problem bywa zwrócenie uwagi na świetnie przecież ugruntowane $\mathrm{w}$ językoznawstwie, a podkreślane $\mathrm{z}$ mocą przez Noama Chomsky'ego rozróżnienie kompetencji i wykonania. Wykonanie właśnie ma być tym, co jest obciążone nieistotnymi z punktu widzenia teorii języka idiosynkrazjami, tym zaś, co teoria ma opisywać, jest wyidealizowana kompetencja.

\footnotetext{
${ }^{2}$ Podobny pogląd wypowiadał też m.in. Max Cresswell (1973: 2-3), który proponował odróżnienie abstrakcyjnych a-języków, podlegających opisowi syntaktycznemu i semantycznemu, i faktycznie używanych u-języków, którym jakaś przyszła pragmatyczna teoria użycia przyporządkuje a-języki jako ewentualne modele.
} 
Uważam jednak, że to odróżnienie n i e wyczerpuje zagadnienia, fakt zaś, że tak często $\mathrm{w}$ tym kontekście jest przywoływane jako wyczerpujące, jest jedną z przyczyn, dla których problem właściwego zasięgu idealizacji wciąż jest niedostatecznie wyraziście dostrzegany i nie dość intensywnie badany. W myśl tego odróżnienia bowiem wykonanie - od tradycyjnie rozumianej kompetencji - różni się ze względu na „ograniczoność pamięci, rozproszenie uwagi, przerzuty uwagi i zainteresowania oraz błędy (przypadkowe lub systematyczne)" $\mathrm{i}, \mathrm{W}$ warunkach [...] stanu idealnego [...] wykonanie stanowi bezpośrednie odzwierciedlenie kompetencji" (Chomsky 1982: 15). Skoro tak, to musimy zdać sobie sprawę, że owa kompetencja, czy też intuicja językowa, jak ją nazywa Chomsky, nie jest rozstrzygająca dla teorii składni, kształtuje się bowiem w zależności od wszystkich głównych nieprzypadkowych, niewynikających z jakichś błędów, aspektów komunikacji językowej - także pozaskładniowych.

Aspektów tych zaś jest bardzo wiele. Mamy tu całą grupę aspektów pragmatycznych, gdzie kompetencja polega na umiejętności wykorzystywania kontekstu pozajęzykowego w komunikacji; wśród nich ważne miejsce zajmują uwarunkowania psychologiczne, decydujące zarówno o możliwościach percepcji dyskursu (i pozajęzykowego kontekstu dyskursu), jak i o ewentualnej ekspresji emotywnej, która może wpływać - lub nie - na inne aspekty.

Mamy też całą grupę aspektów semantycznych, które poza kwestią znajomości znaczeń leksykalnych używanych słów i zwrotów obejmują też duże partie ogólnej wiedzy o świecie uczestników komunikacji i zakładaną przez nich ontologię dyskursu (nie mówiąc już o relacjach logicznych pomiędzy różnymi fragmentami dyskursu i jego językowego kontekstu).

Wreszcie nawet aspekty należące do tradycyjnej gramatyki dalece wykraczają poza wąsko rozumianą składnię, która w oczekiwaniu Chomsky'ego miała być głównym polem działania kompetencji językowej. Wiele tradycyjnych kategorii gramatycznych, takich jak np. policzalne/niepoliczalne, osobowe/ nieosobowe, ożywione/nieożywione, z którymi stowarzyszone są ważne reguły gramatyczne (np. 'czasowniki orzekane o rzeczownikach osobowych odmieniaja się męskoosobowo, a o nieosobowych - niemęskoosobowo'), zawiera ogromną ilość informacji empirycznej o świecie zewnętrznym, mając tym samym wyraźnie semantyczny charakter. Naruszenie wspomnianych reguł wcale nie musi zatem mieć charakteru błędu składniowego, może natomiast być wyrazem ekscentrycznych poglądów na świat pozajęzykowy (lub też specyficznych emocji). $Z$ reguły np. neandertalczyków uważa się za dość ludzkich, by uznać rzeczownik 'neandertalczyk' za osobowy i stosować męskoosobową odmianę orzekanych o nim czasowników ('Neandertalczycy wyginęli') - w przeciwieństwie do australopiteków, które nie są dość ludzkie ('Australopiteki wyginęły'). 
Czy jednak zdania 'Neandertalczyki wyginęły' albo 'Australopitecy wyginęli' są rzeczywiście błędami składniowymi? Czy nie jest raczej tak, że pierwsze jest po prostu p o g a r d l i w e a drugie (na przykład ironicznie) a f i r m u j a c e?

Spostrzeżenia te ukazują wyraźnie, że powoływanie się na kompetencję jako na empiryczną podstawę teorii składni, jak to robi $\mathrm{Chomsky}^{3}$, byłoby racjonalne tylko wówczas, gdybyśmy dysponowali jednolitą i szczegółową teorią wszystkich aspektów łącznie (nazwijmy taką teorię KTJ - 'kompletną teorią języka'). W przeciwnym razie nie dysponujemy żadnym kryterium, które pozwalałoby właściwie adresować wskazania takiej kompetencji, tzn. uznać je jako świadectwo na rzecz konkretnej teorii syntaktycznej. Nie mamy bowiem metody oddzielenia tego, co pochodzi od komponentu kompetencji semantycznej bądź pragmatycznej.

Dobrą ilustrację, dlaczego tak jest, przedstawił w latach dziewięćdziesiątych Carson T. Schütze (1996) w głośnej książce The Empirical Base of Linguistics. Zauważył on mianowicie, że tym, co może wykazać eksperyment, nie jest bynajmniej gramatyczność wyrażenia (czyli jego poprawność składniowa), lecz jedynie jego akceptowalność w danym układzie eksperymentalnym (czyli, w najlepszym razie poprawność tout court, w najgorszym zaś - po prostu funkcjonalność komunikacyjna):

Lingwiści mogą budować argumenty dotyczące gramatyczności zdania, ale wszystko, co lingwistycznie nieukształtowany podmiot [badany] może zrobić, to ocenić jego akceptowalność (Schütze 1996: 26) .

${ }^{3}$ „Gdy proponuje się jakąś procedurę operacyjną, trzeba koniecznie pamiętać o tym, że musi ona być sprawdzona co do adekwatności (dokładnie tak samo, jak teorię intuicji językowej gramatykę - winno się poddać testowi na adekwatność) poprzez zestawienie jej ze standardem, jakiego dostarcza owa utajona znajomość języka, którą usiłuje ona określić i opisać. Tak więc na przykład jakiś zaproponowany operacyjny test segmentacji wypowiedzeń na wyrazy winien przy dużej liczbie przykładów istotnych i wyraźnych spełniać empiryczny warunek zgodności z intuicją językową rodowitego użytkownika języka, w przeciwnym wypadku będzie on bez wartości" (Chomsky 1982: 38; por. też: 40 i 44). Perspektywa tu zarysowana ukazuje, że program Chomsky'ego, który w językoznawstwie - z racji historycznego sporu $\mathrm{z}$ ultraempirystycznym behawioryzmem - uważany jest raczej za racjonalistyczny niż empirystyczny, w rzeczywistości jest zbyt empirystyczny w stosunku do tego, czego można racjonalnie oczekiwać od teorii języka.

4 Wykazywanie gramatyczności/akceptowalności rozumie się tu $\mathrm{w}$ szerokim sensie, jako odpowiadanie na pytanie, czy dane wyrażenie jest gramatyczne/akceptowalne. Obejmuje to w szczególności przypadki, w których odpowiedź ta jest negatywna, czyli te, w których wykazuje się de facto $\mathrm{n}$ i e g r a ma t y c z n o ść resp. n i e a k c e p t o w a $1 \mathrm{n}$ o ść. Duża część bazy empirycznej generatywistycznej teorii składni to właśnie takie negatywne przypadki (z racji przewagi kryterium falsyfikacjonistycznego nad weryfikacjonistycznym w ogólnej metodologii nauki) i to właśnie $\mathrm{w}$ takich przypadkach utożsamianie poprawności składniowej 
Akceptowalność zaś, z punktu widzenia badanych, zależy - m.in. od:

- pozycji domniemanej anomalii gramatycznej w zdaniu;

- liczby i etykietowania dostępnych opcji w formularzu ankiety;

- tego, czy o poprawność przykładu pytano przed czy po ekspozycji na ten przykład;

- znajomości testowanej teorii lingwistycznej ${ }^{5}$;

- ogólnego wykształcenia;

- przekonań na temat natury świata;

- układu eksperymentalnego (sformułowanie kwestionariusza, porządek przykładów, liczba powtórzeń itp.);

- kontekstu pozajęzykowego;

- użyteczności komunikacyjnej badanego przykładu;

- komplikacji składniowej przykładu (np. liczby zagnieżdżeń);

- i wielu innych rzeczy...

Upoważnia to Schützego (1996: 204) do powtórzenia za Labovem, że „Intuicja jest mniej regularna i trudniejsza do zinterpretowania niż mowa" i do konkluzji, że ,intuicje [bynajmniej] nie są empirycznymi danymi pierwotnymi, lecz złożonymi reakcjami behawioralnymi" (Schütze 1996: 50).

Wymowa tej konkluzji jest dla metodologii empirystycznej w językoznawstwie surowa: zbyt często interpretacja eksperymentów, które rzekomo potwierdzają obowiązujący wariant teorii składni ${ }^{6}$ lub obalają konkurencyjny, jest bardziej wątpliwa, niż sama ta teoria. Schütze zdaje się jeszcze mieć nadzieję, że liczne błędy metodologiczne, jakie wskazuje w cytowanych przez siebie badaniach, mogłyby być teoretycznie wyeliminowane, gdyby tylko badacze dostatecznie uważnie uwzględniali wszystkie wymienione czynniki zaburzające (lub zadbali o wyeliminowanie tych, które da się wyeliminować); innymi słowy gdyby przyłożyli taką wagę do ustawienia układu eksperymentalnego, jak to jest standardem w naukach przyrodniczych. Jego własne próby na tym polu dają jednak czysto negatywny wynik: w s z y stki e przypadki eksperymentów, które oryginalnie miały potwierdzać jakieś fragmenty teorii lingwistycznej (lub obalać kontrhipotezy), po 'poprawionej' analizie Schützego przestawały

z poprawnością tout court jest wyraźnym błędem: wykazanie $\mathrm{n}$ i e p o p r a w n o ś c i tout court w żadnym razie nie przesądza, że zachodzi też niepoprawność składniowa. Źródło niepoprawności może być gdzie indziej (nawet jeśli informatorom zdaje się, że chodzi o składnię).

${ }^{5}$ Wielu uczonych zauważa - znacznie wcześniej niż Schütze pisała o tym w Polsce Barbara Stanosz (1999: 130) - że tym, co niejednokrotnie bada się w eksperymentach lingwistycznych jest nie tyle intuicja czy kompetencja językowa, ile intuicja czy kompetencja j ę z y k o$\mathrm{z} \mathrm{n}$ a w c z a.

${ }^{6}$ A na teorii składni niektórzy językoznawcy (zwłaszcza ze szkoły Chomsky’ego) budują teorię języka w ogóle - jest to dla nich podstawowy komponent ogólnej teorii lingwistycznej. 
cokolwiek potwierdzać czy też coś wykluczać. Okazało się, że poprawianie eksperymentów de facto całkowicie u s u w a ł o ich wyniki z bazy empirycznej językoznawstwa.

W świetle tego, co powiedzieliśmy wyżej, trudno uznać to za wynik zaskakujący. Przy dostatecznie ‘dużym' zjawisku językowym, uzyskanym eksperymentalnie danym nie da się w zasadzie przyporządkować konkretnej wyjaśniającej teorii; dane te mogą być bowiem wyjaśniane za pomocą bardzo wielu różnych kombinacji teorii i hipotez opisujących różne fragmenty KTJ.

W reakcji na taki stan rzeczy można ograniczyć się do badania 'małych' i izolowanych zjawisk językowych, dla których da się określić działanie wszystkich relewantnych czynników. Przykładem takich badań jest np. praca Stevena Pinkera „Rules of language”, w której ogranicza on swoje badania do odmiany czasu przeszłego ( $\mathrm{w}$ angielszczyźnie). Autor zauważa, że jest to „możliwy do wyizolowania podsystem, w którym mechanizmy gramatyczne mogą być badane w szczegółach, bez złożonych interakcji z resztą języka" (Pinker 1991: 531) ${ }^{7}$.

Język jednak nie dzieli się na takie izolowane podsystemy bez reszty; niewiele tylko zjawisk językowych można w ten sposób wyizolować. W szczególności wielkie zagadnienia teorii składni z pewnością do takich nie należą. Jeżeli chcemy je badać, musimy wybrać inną drogę. Musimy dalej szukać właściwej odległości między tym co czysto formalne, a tym co faktyczne w języku, nie ograniczając się do konstatacji różnicy między wykonaniem a kompetencją. Musimy pójść w kierunku, który wskazywał Schütze. Jak pisał:

[...] jest to wyobrażalne, że kompetencja w sensie statycznie reprezentowanej wiedzy nie istnieje. Być może jest tak, że dany ciagg [wyrażeń] jest generowany, lub obliczany, tylko kiedy to jest konieczne, i że to wymogi danej sytuacji określają jak takie obliczenie jest przeprowadzane, na przykład przez porównanie do prototypowych struktur zdaniowych przechowywanych w pamięci. Taki scenariusz oznaczałby konieczność poważnego ponownego przemyślenia celów, jakie stoją przed lingwistyką (Schütze 1996: 20).

Jednym z kierunków, w jakich przemyślenie takie mogłoby pójść, jest aktualizacja ogólnych zasad i pojęć metodologii nauki, implementowanych w języ-

${ }^{7}$ Często jednak i w takim wypadku można łatwo przecenić stopień wyizolowania zjawiska. Przykładem są badania nad właściwą formą kwantyfikatora w tzw. donkey sentences. Zazwyczaj uważano, że eksperymenty pokazują zależność wyboru kwantyfikatora od pewnych własności lingwistycznych, wchodzących $w$ grę wyrażeń. W pewnym momencie okazało się jednak, iż można argumentować, że na wybór tej formy wpływają (implicytne) przekonania ontologiczne badanych (Geurts 2002; Pietrulewicz, Tałasiewicz 2010). 
koznawstwie. Zasady te i pojęcia - w szczególności samo centralne dla niniejszych rozważań pojęcie empiryczności - przyjmowane są w naukach szczegółowych, w tym także w językoznawstwie, z pewnym opóźnieniem w stosunku do aktualnego stanu wiedzy, jakiej dostarcza na ich temat metodologia ogólna. To zrozumiałe, zawsze $\mathrm{w}$ ten sposób idee jednej dyscypliny przenikają do drugiej, zewnętrzni 'użytkownicy' językoznawstwa, w tym filozofowie, nie inaczej przecież postępują $\mathrm{z}$ językoznawstwem. W wypadku filozofii nauki dystans jest jednak szczególnie dotkliwy: obraz jej, funkcjonujący w obiegu dyscyplin szczegółowych, w bardzo małym stopniu przypomina jej stan aktualny. W 'użyciu' wciąż jest metodologia $\mathrm{z}$ lat siedemdziesiątych $\mathrm{XX}$ wieku, kiedy dominującą pozycję w filozofii nauki miały spory wokół pojęcia testowalności (falsyfikowalności), związane z nazwiskami Karla Poppera, Thomasa Kuhna czy Imre Lakatosa. Tymczasem metodologia ogólna zupełnie się od tamtych czasów zmieniła - w latach osiemdziesiątych i dziewięćdziesiątych dzięki pracom takich filozofów, jak Larry Laudan, Peter Lipton czy Bas van Fraassen (w Polsce Adam Grobler), nastąpił w filozofii nauki radykalny przełom, w wyniku którego filozofia nauki w swoim centrum postawiła pojęcie najlepszego wyjaśnienia, pojęcie testowalności pozostawiając $\mathrm{w}$ dalszym planie. Zmieniło się - co za tym idzie - także pojęcie empiryczności. Ogólnie nie oczekuje się już, że teoria musi bezwarunkowo generować sprawdzalne doświadczalnie przewidywania, jeżeli dostarcza dobrych wyjaśnień ${ }^{8}$.

Czym zaś są dobre wyjaśnienia - to zależy od wymogów i oczekiwań danej dyscypliny. Od teorii składni, która jest tutaj naszym głównym przykładem, oczekujemy m.in. wyjaśnienia, w jaki sposób znaczenia i odniesienia wyrażeń składowych wyznaczają znaczenie i odniesienie wyrażenia złożonego (kompozycjonalność), czy w jaki sposób składnia wpływa na relacje logiczne pomiędzy zdaniami, w szczególności na relację wynikania; a także dostarczenia dobrych narzędzi detekcji i unieszkodliwiania amfibologii (czyli wieloznaczności składniowych), czy wreszcie wskazania sposobów wydobywania niuansów znaczeniowych z różnic dostępnych analiz struktury składniowej danego wyrażenia. Nie trzeba natomiast oczekiwać od niej tego, czego przez lata się oczekiwało - i czego niestety nierzadko wciąż się oczekuje: zdania sprawy z przekonań przeciętnego użytkownika języka co do poprawności gramatycznej. Dzięki nowemu rozumieniu empiryczności teoria, która dobrze realizuje wspomniane zadania, może pozwolić sobie na to, by - mówiąc skrótowo - nie zgadzać się z opiniami przeciętnych użytkowników. W szczególności może ona klasyfikować jako poprawne składniowo wyrażenia skądinąd uznawane po-

${ }^{8}$ Podręcznikiem metodologii, który uwzględnia wspomnianą zmianę perspektywy w filozofii nauki, jest książka Groblera (2006). 
wszechnie za nieakceptowalne. Rozwijając ten skrót, powiedzmy od razu, że formalnie rzecz biorąc teoria taka oczywiście nie przeczy doświadczeniu, lecz uzgadnia się z nim za pomocą hipotez z pasa ochronnego, którym w wypadku składni jest semantyka (z ontologia) i pragmatyka (z psychologia poznania). Uzgodnienie to polega na wskazaniu semantycznych (w tym: ontologicznych) i pragmatycznych (w tym: psychologicznych) źródeł stwierdzanego doświadczalnie poczucia nieakceptowalności danej konstrukcji, którą przyjęta teoria składni uznaje za poprawna.

Teorią składni, która została stworzona z myślą o realizacji wymienionych tutaj oczekiwań eksplanacyjnych, była tzw. gramatyka kategorialna - pierwsza w historii formalna teoria syntaktyczna, obejmująca swoim postulowanym zasięgiem także język naturalny9.

Zasadnicze idee gramatyki kategorialnej sformułował przed wojną Kazimierz Ajdukiewicz (1935/1985) i od tego czasu rozwijała się ona intensywnie do lat pięćdziesiątych XX wieku (prace Yehoshui Bar-Hillela i Joachima Lambeka). W latach sześćdziesiątych odsunięta na boczny tor za sprawą sukcesów gramatyki generatywnej Chomsky'ego, w siedemdziesiątych powróciła do głównego nurtu dzięki pracom wspomnianego Geacha i Cresswella (a także dzięki wyraźnemu osłabieniu impetu teorii generatywistycznej, trapionej $\mathrm{z}$ jednej strony kłopotami z semantyką, a z drugiej - brakiem wyraźnych postępów w poprawianiu adekwatności empirycznej $)^{10}$. Odtąd aż do dzisiaj okres bardzo szybkiego rozwoju formalnego przypadł na lata osiemdziesiąte (głównymi postaciami tego ożywienia byli Wojciech Buszkowski i Johan van Benthem) - gramatyka kategorialna jest jednym z najważniejszych paradygma-

9 Gramatyka kategorialna to gramatyka oparta na związku funkcyjnym (w matematycznym sensie), czyli taka, w której wszelkie wyrażenie złożone jest wartością funkcji wskazanej przez jeden z członów tego wyrażenia (funktor/operator), a argumentami tej funkcji są pozostałe człony tego wyrażenia. Innymi słowy, w każdym wyrażeniu złożonym wyróżniony jest jeden człon, który operuje na pozostałych, podporządkowanych mu członach i łączy je w jednolitą całość. Ponieważ równoległa zależność dotyczy semantycznych korelatów wyrażeń, gramatyka ta wyjaśnia niejako automatycznie możliwość interpretacji semantycznej nieograniczonej liczby wyrażeń złożonych i ustalenia niektórych relacji logicznych pomiędzy nimi. [Wyjaśnienie to dodaję ze względu na pojawiające się niekiedy nieporozumienie, że gramatyka kategorialna jest to gramatyka, która postuluje jakieś kategorie gramatyczne (jak to sugerowałaby nazwa). Owszem, postuluje, ale j a k i és kategorie gramatyczne występują praktycznie w każdej gramatyce; nie jest to jej cechą wyróżniającą.]

${ }^{10}$ Ważną przyczyną była też okoliczność, że dopiero w 1967 r. ukazała się po angielsku kluczowa praca Ajdukiewicza (w zbiorze McCall 1967). Jej oryginał opublikowano w najważniejszym ówcześnie języku naukowym świata - po niemiecku - ale wskutek wypadków historycznych język ten wkrótce przestał być najważniejszy i koncepcja gramatyki kategorialnej pozostawała stosunkowo mało znana. 
tów badawczych w teorii składni, zwłaszcza w kontekście maszynowego przetwarzania języka naturalnego (zob. Buszkowski 1989; van Benthem, ter Meulen 1997).

Jak łatwo się domyślić, podejmowane były próby połączenia gramatyki kategorialnej $\mathrm{z}$ gramatyką generatywną, pozostającą od lat pięćdziesiątych niezwykle wyrazistym (choć zmieniającym się) paradygmatem badań nad składnią na terenie językoznawstwa ${ }^{11}$. Jedną z takich prób była praca Davida Lewisa (1970), który zaproponował, by tzw. struktury głębokie były generowane przez gramatykę kategorialną, a struktury powierzchniowe - przez transformacyjny komponent gramatyki generatywnej; miało to zapewnić gramatyce logiczną spójność (dzięki funkcyjnej strukturze gramatyki kategorialnej) i zarazem dopasowanie do rzeczywistych form językowych (dzięki rzekomo osiagającej takie dopasowanie transformacyjnej gramatyce generatywnej). Połączenie to okazało się jednak zbyt mechaniczne i wskutek tego zbyt heterogeniczne: żadna jednolita zasada nie unifikowała tego systemu i pomysł Lewisa nie znalazł wielu naśladowców, choć próby połączenia zalet obu teorii (choć już nie samych teorii) - trwały nadal. Wśród nich trzeba wspomnieć o pracach Geralda Gazdara, Ivana Saga i ich współpracowników, którzy pozostając wewnątrz tradycji generatywnej, włączyli do gramatyki ustrukturalizowany leksykon, którego konstrukcja, oparta na teorii typów, wykazuje wyraźne pokrewieństwo $\mathrm{z}$ funktorową strukturą gramatyki kategorialnej ${ }^{12} . \mathrm{Z}$ drugiej strony należy wymienić przede wszystkim publikacje Richarda Montague $(1974)^{13}$, który czysto abstrakcyjną gramatykę kategorialną wyposażył w reguły interpretacyjne, pozwalające zrekonstruować w niej spory fragment naturalnego języka angielskiego. Dzięki temu posunięciu gramatyka ta mogła po raz pierwszy stanać w szranki konkurencji, o jak najlepsze dopasowanie do rzeczywistej postaci akceptowalnych zdań języka naturalnego.

Możliwości tej sprzyjał też wspomniany wyżej burzliwy rozwój formalnej strony gramatyki kategorialnej, kiedy to do celów gramatycznych zaczęto wykorzystywać cały aparat matematycznej teorii typów, dzięki czemu zasób dostępnych konstrukcji gramatycznych (a więc i możliwości wiernego odtwa-

\footnotetext{
${ }^{11}$ Szczegółów tego paradygmatu podawać tutaj nie będę. Zakładam, że - w przeciwieństwie do gramatyki kategorialnej, która powstała na gruncie filozoficznym - gramatyka generatywna jest czytelnikowi doskonale znana.

${ }^{12}$ Uczeni ci są autorami koncepcji znanych jako GPSG (Generalized Phrase-Structure Grammar) i HPSG (Head-driven Phrase Structure Grammar). Zob. Gazdar i in. (1985); Pollard, Sag (1994).

${ }^{13}$ Notabene doktoranta Alfreda Tarskiego, wybitnego polskiego logika, członka szkoły lwowsko-warszawskiej, pracującego wtedy już w Berkeley, w Kalifornii.
} 
rzania dostępnych rzekomo w doświadczeniu tzw. struktur powierzchniowych) znacznie się poszerzy1 ${ }^{14}$. W dalszym planie rozwój ten okazał się jednak źródłem poważnej trudności, która trapi gramatykę kategorialną do dzisiaj. Otóż teoria ta, która do lat siedemdziesiątych oparta była na nielicznych, niezwykle prostych i bardzo intuicyjnych zasadach (przez co zyskiwała sobie szacunek tych, którzy chcieli wyrażenia złożone rozumieć, a nie tylko je 'generować'), podzieliła los gramatyki generatywnej, rozszczepiając się na niezliczone warianty, różniące się zasobem przyjmowanych w gruncie rzeczy ad hoc modyfikacji. Uwidocznił się tu ten sam mechanizm, który opisaliśmy powyżej, że im więcej rzeczywistych konstrukcji wyjaśnia dana teoria składni, tym mniej zrozumiałe jest oferowane przez tę teorię wyjaśnienie.

$\mathrm{W}$ rezultacie, $\mathrm{z}$ powodu błędnego pojmowania rangi zgodności z tzw. doświadczeniem, współczesny stan teorii składni - zarówno w tradycji generatywistycznej, jak i w tradycji kategorialnej - nie może być zadowalający dla nikogo, kto chciałby od teoretyków składni uzyskać jakieś wiążące wytyczne, choćby najogólniejszej natury, co do tego, na czym w istocie polega składanie wyrażeń w języku naturalnym. W szczególności stan ten nie jest zadowalający dla filozofa języka. Sytuację zwięźle podsumowuje Pauline Jacobson, redaktor naczelna czasopisma Linguistics and Philosophy (utworzonego w 'złotych' latach siedemdziesiątych jako platforma porozumienia między językoznawcami i filozofami). W jubileuszowym tomie, w artykule pod znaczącym tytułem „The (dis)organisation of the grammar: 25 years" pisze:

Nie ulega wạtpliwości, że w okresie 25 lat od powstania Linguistics and Philosophy byliśmy świadkami eksplozji naszego rozumienia lingwistycznej semantyki. Można jednak przekonywać, że na jednym polu uczyniliśmy niewielki postęp - zaprawdę, chciałabym tu zasugerować, że nawet cofnęliśmy się. Dotyczy to fundamentalnej kwestii ogólnej organizacji i architektury gramatyki - w szczególności tego, jak systemy składni i semantyki współpracują (lub nie współpracuja) ${ }^{15}$ (Jacobson 2002).

\footnotetext{
${ }^{14}$ Współczesną gramatykę kategorialną nazywa się często z tego powodu Flexible Categorial Grammar (FCG) albo Combinatory Cateorial Grammar (CCG). Zwięzły przegląd innowacji można znaleźć w: Steedman (2000: 40-52).

15 „There is no doubt that the 25 years since the launching of Linguistics and Philosophy have witnessed an explosion in our understanding of linguistics semantics. There is, however, one area in which we have arguably made little progress - indeed I wish to suggest here that we have perhaps gone backwards. And this concerns the fundamental question of overall organization and architecture of the grammar - in particular, how the systems of syntax and semantics work (or don't work) together" (Jacobson 2002: 601).
} 
Jak starałem się w tym tekście wykazać, remedium na tę sytuację jest modyfikacja pojęcia empiryczności i rezygnacja z tzw. adekwatności empirycznej jako naczelnego kryterium ewaluacji teorii składni. Składnia jest aspektem języka, który w ogólności (nie licząc pewnych szczególnych izolowanych podsystemów) jest niewyodrębnialny spośród innych aspektów; teoria składni, by oferować dobre wyjaśnienia, musi być teorią w wysokim stopniu idealizacyjną - w stopniu znacznie wyższym niż ten, który jest wymagany do przezwyciężenia dychotomii kompetencja-wykonanie.

W książce Philosophy of Syntax (Tałasiewicz 2010) ${ }^{16}$ podałem teorię, która jest próbą realizacji tego postulatu. Stanowi ona filozoficznie pogłębioną wersję klasycznej gramatyki kategorialnej, w której nie wszystkie przekształcenia dopuszczalne w teorii typów znajdują zastosowanie, lecz tylko te, którym można nadać specyficzny sens składniowy. Za cenę tego, że 'przewidywania' tej teorii dość znacznie odbiegają od naturalnego poczucia akceptowalności ${ }^{17}$, teoria ta w wysokim stopniu realizuje wskazane wyżej cele eksplanacyjne, których wypełnienia można i należy oczekiwać od dobrej teorii składni; spełnia zarazem podstawowe wymogi, jakie narzuca na koncepcję składni postulat psychologicznej realności wchodzących w grę procesów akwizycji i produkcji mowy.

Czy ta konkretna teoria jest dobra - czas pokaże. Nie jest ona tematem niniejszego tekstu - nie będę w szczególności podawał żadnych szczegółów, odsyłając zainteresowanego czytelnika do publikacji źródłowych - jest tylko przykładem, że w kierunku, który tutaj zarysowałem, da się podążać. Tutaj najważniejsze jest to, że właśnie ten kierunek - a więc potrzeba zwiększania głębi eksplanacyjnej teorii języka kosztem wąsko rozumianej adekwatności empirycznej - jest słuszny, zwłaszcza jeżeli zależy nam na tym, by wyniki osiagnięte w jednej dyscyplinie były rozumiane i uwzględniane w sąsiednich.

\section{Bibliografia}

Ajdukiewicz, K. [1935] 1985. „O spójności syntaktycznej”, [w:] Język i poznanie 1, Warszawa: PWN, 222-242.

Ajdukiewicz, K. [1960] 1985. „Związki składniowe między członami zdań oznajmujących", [w:] Język i poznanie 2, Warszawa: PWN, 344-355.

${ }^{16}$ Niektóre tematy, które podejmuję w tej książce, opracowałem wcześniej po polsku w pracy Filozofia składni (Tałasiewicz 2006). Tak się jednak składa, że akurat rozważania metodologiczne uległy stosunkowo największemu wzbogaceniu i wersja (2006) jest pod tym względem mało reprezentatywna.

$17 \mathrm{~W}$ pełni poprawny składniowo jest w myśl tej teorii klasyczny przykład Chomsky’ego: 'Bezbarwne zielone idee śpią wściekle'. 
Benthem, J. van, Meulen, A. ter (red.), 1997. Handbook of Logic and Language, Amsterdam: Elsevier Science.

Buszkowski, W. 1989. Logiczne podstawy gramatyk kategorialnych Ajdukiewicza-Lambeka, Warszawa: PWN.

Chomsky, N. [1965] 1982. Zagadnienia teorii składni, tłum. I. Jakubczak, Wrocław: Ossolineum.

Cresswell, M. 1973. Logics and Languages, London: Methuen.

Gazdar, G., Klein, E. H., Pullum, G. K., Sag, I. A. 1985. Generalized Phrase Structure Grammar, Oxford-Cambridge, MA: Blackwell, Harvard University Press.

Geach, P. T. 1970. „A program for syntax”, Synthese 22, 3-17.

Geurts, B. 2002. „Donkey business”, Linguistics and Philosophy 25, 129-156.

Grobler, A. 2006. Metodologia nauk, Kraków: Znak.

Jacobson, P. 2002. „The (dis)organisation of the grammar”, Linguistics and Philosophy $25,601-626$.

Lewis, D. 1970. „General semantics”, Synthese 22, 18-67.

McCall, S. (red.), 1967. Polish Logic 1920-1939, Oxford: Oxford University Press.

Montague, R. 1974. Formal Philosophy, New Haven: Yale University Press.

Pinker, S. 1991. „Rules of language”, Science. New Series 253 (5019), 530-535.

Pietrulewicz, N., Tałasiewicz, M. 2010. „Donkey sentences and cognitive representation of quantificational domain", referat na konferencji Coglang, Łódź.

Pollard, C., Sag, I. A. 1994. Head-driven Phrase Structure Grammar, Chicago: University of Chicago Press.

Schütze, C. T. 1996. The Empirical Base of Linguistics, Chicago: University of Chicago Press.

Stanosz, B. [1974] 1999. „Status poznawczy semantyki”, [w:] Logika języka naturalnego, Warszawa: Polskie Towarzystwo Semiotyczne, 123-139.

Steedman, M. 2000. The Syntactic Process, Cambridge, MA: MIT Press.

Tałasiewicz, M. 2006. Filozofia składni, Warszawa: Semper.

Tałasiewicz, M. 2010. Philosophy of Syntax. Foundational Topics, Berlin-New York: Springer. 